\title{
Performance of An Airlift Membrane Bioreactor Under Different Aeration Rates
}

\author{
Mahsa Kazemzadeh-Afshar, Mohammad-Hossein Sarrafzadeh ${ }^{*}$ and \\ Mohammad-Reza Mehrnia
}

School of Chemical Engineering, College of Engineering, University of Tehran, P.O. Box 11155-4563, Tehran, Iran

\begin{abstract}
The treatment of a synthetic oily wastewater in an airlift submerged membrane bioreactor (AMBR) has been studied. A flat sheet Kubota membrane has been used for this purpose in the reactor with a working volume of $19 \mathrm{~L}$. The volumetric oxygen transfer coefficient, oxygen uptake rate, treatment efficiency and fouling intensity were investigated for various aeration rates $\left(0.2,0.5,0.7\right.$ and $\left.1 \mathrm{~m}^{3} / \mathrm{h}\right)$. Based on the results, a COD removal efficiency of more than $93 \%$ even for the lowest aeration rate - is reported. However, increasing the aeration rate resulted in higher $\mathrm{k}_{\llcorner} a$ and higher microbial activity. The high aeration intensity resulted in breakage of activated sludge flocs and hence reduction in mean flocs size and release of extracellular polymeric substances (EPS). At an aeration intensity as high as $1 \mathrm{~m}^{3} / \mathrm{h}$, the maximum irreversible fouling was observed which is due to higher concentration of EPS and colloids that are the major foulants. Although the aeration may scour the membrane surface and avoid the formation of cake layer, it could induce more pore blocking fouling. In the studied range, the $0.7 \mathrm{~m}^{3} / \mathrm{h}$ is found to be the optimum aeration rate and the alteration of the aeration rate deteriorated the AMBR's performance.
\end{abstract}

Keywords: Airlift MBR, Aeration, EPS, Fouling, Mass transfer coefficient, Oxygen uptake rate.

\section{INTRODUCTION}

In submerged membrane bioreactors (SMBR), pollutants are treated in an aeration tank and a membrane system separates the microorganisms from wastewater while the suspended solids are held back within the bioreactor [1]. Because of higher biomass concentration, oxygen consumption in membrane bioreactor (MBR) is larger than a traditional activated sludge process and more oxygen must be supplied by aeration [2]. In SMBRs, the main power requirement is associated with the aeration which performs three essential tasks [3]:

- Providing dissolved oxygen

- $\quad$ Mixing

- Scouring the membrane surface

In SMBRs, spargers are normally placed below the membrane modules so that air bubbles rise through the membrane surface to fight particle deposition upon the membrane. Therefore, aeration can decline membrane fouling which is usually referred to as the most serious problem in the operation of MBRs.

However, there exists an optimum aeration rate to significantly lessen the membrane fouling. An aeration

*Address correspondence to this author at the School of Chemical Engineering, College of Engineering, University of Tehran, P.O. Box 111554563, Tehran, Iran; Tel: (+98)21-61112185; Fax: (+98)21-66957784;

E-mail: sarrafzdh@ut.ac.ir rate higher than such the optimum value is believed to have no significant effect on the membrane fouling due to some adverse changes in biomass characteristics. Based on experimental works, it has been reported that when MBRs are operated at suitable conditions, a stable reversible fouling resistance is encountered. Yet, for improper operational conditions, the reversible fouling resistance increases exponentially during the filtration process [4].

The membrane fouling is characterized by decline in membrane permeate and increase in energy consumption; the both are undesirable. One of the ways to reduce fouling is to use an airlift SMBR in which the flow of bubbles imposes more cross flow, turbulence and shear stress on the membrane surface and intensifies mass back-transport of the deposited particles thereon. Airlift membrane bioreactors (AMBR) have been used to improve filtration performance and to minimize membrane fouling [5] and also it was revealed by some CFD simulations that a proper distribution of air across the membrane leads to a better distribution of shear stress and thus, it enhances the efficiency of the gas-liquid, two-phase process in AMBRs [6]. The effect of fouling should be considered both on the filtrate quantity (permeate flux) and its quality. Despite the undesirable influence of fouling on membrane permeability, a considerable enhancement in COD removal performance occurs due to biodegradation initiating in the biofilm and further filtration by the cake layer [7]. 
Oxygen supply normally counts for more than $70 \%$ of total energy cost of wastewater treatment plants and for MBRs it reaches up to $80 \%$ of the total energy consumption. Consequently, a flawless design of the aeration system and the related installations are prerequisites to an efficient operation $[8,9]$.

In aerobic processes, a critically limiting factor is provision of sufficient oxygen for metabolism of the microorganisms [10]. The dissolved oxygen (DO) concentration is a limiting factor in high oxygen demanding processes especially when a high concentration of suspended materials changes the rheological properties of the culture and lower the oxygen transfer rate. Therefore, the oxygen mass transfer coefficient plays a decisive role in the performance of bioreactors [11]. The oxygen transfer rate (OTR) is a function of the volumetric mass transfer coefficient, $\mathrm{k}_{\mathrm{L}} a$. This coefficient is influenced by biomass characteristics (as a heterogeneous mixture of different shapes, sizes, particles densities), chemical and physical properties of the fluid, design of the aeration system, composition of the solution, agitation and oxygen superficial gas velocity [12]. Additionally, an $\alpha$-factor as a correction means is used along with $\mathrm{k}_{\mathrm{L}} a$ in an actual system to depict the oxygen transfer in the industrial plants $[13,2]$. Of the biomass characteristics studied, only solids concentration, the carbohydrate fraction of the EPS (EPSc) and the chemical oxygen demand (COD) concentration of the SMP (SMP $\left.P_{C O D}\right)$ were found to affect the $k_{L} a$ and $\alpha$-factor [14].

However, the DO concentration in bioreactors is also affected by microorganisms' oxygen uptake rate (OUR) [15]. Moreover, the presence of extracellular polymeric substances as the most important foulants in MBR also depends on the DO concentration. However, the membrane fouling should not merely be attributed to EPS concentration $[16,17]$. Elsewhere, it has been demonstrated that the diverse types of EPS affect membrane fouling in different ways [18].

In this paper, the influence of aeration intensity on mass transfer coefficient, oxygen uptake rate, COD removal and membrane fouling were investigated in an airlift submerged MBRs at different aeration intensities.

\section{MATERIALS AND METHODS}

\subsection{Experimental Setup}

An airlift submerged membrane bioreactor with its details presented in Figure $\mathbf{1}$ was used in the current study to treat a synthetic oily wastewater with the composition presented in Table 1. The bioreactor was made of Plexi-glass with a working volume of $19 \mathrm{~L}$. Two $85^{\circ}$-angled baffle plates divided the bioreactor into one riser zone and two down-comer zones. A flat sheet membrane module was submerged vertically in the riser between the two baffle plates located above the air diffuser. The membrane was made of chlorinated polyethylene (KUBOTA Co. Ltd) with mean pore size of $0.45 \mu \mathrm{m}$. The properties of membrane are summarized in Table 2. Mixed liquor suspended solids concentration varied in the range of $3500-5500(\mathrm{mg} / \mathrm{L})$. The $\mathrm{pH}$ of broth fell in the range of 7-8. The air rate was adjusted by a flow-rate meter and supplied through air diffuser that was fixed below the membrane module. The airflow rates were selected as $0.2,0.5,0.7$ and 1 $\mathrm{m}^{3} / \mathrm{h}$. The dissolved oxygen concentration exceeded 2 $\mathrm{mg} / \mathrm{L}$ in the bioreactor all over the experiments.

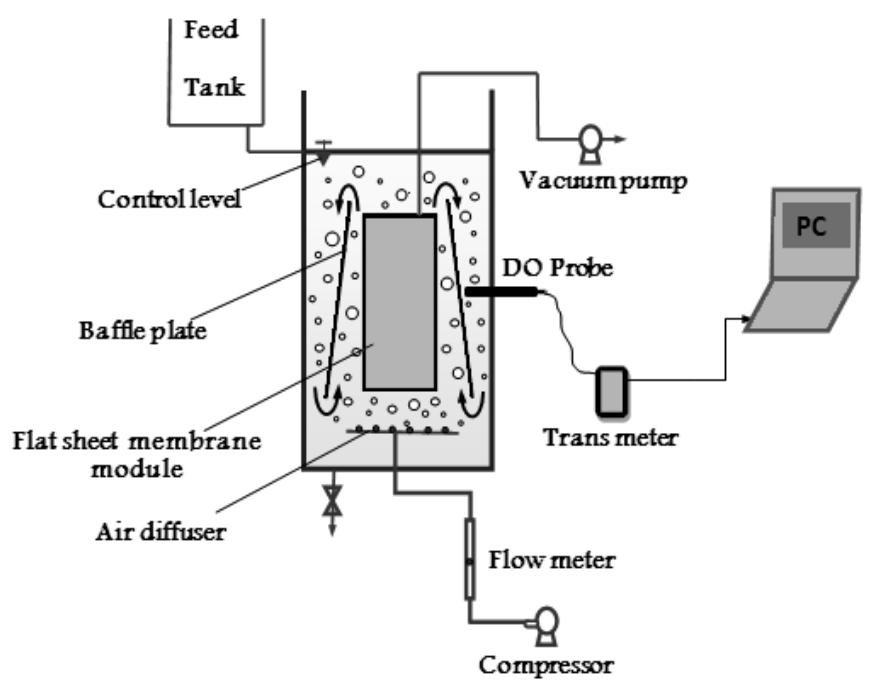

Figure 1: Experimental set-up of the airlift membrane bioreactor (AMBR) used in this study.

Table 1: Composition of Synthetic Wastewater

\begin{tabular}{|c|c|}
\hline Substance & Concentration $(\mathbf{m g} / \mathbf{L})$ \\
\hline \hline Hexadecane & 950 \\
\hline$\left(\mathrm{NH}_{4}\right)_{2} \mathrm{SO}_{4}$ & 215 \\
\hline$\left(\mathrm{NH}_{4}\right) \mathrm{H}_{2} \mathrm{PO}_{4}$ & 38 \\
\hline $\mathrm{NaHCO}_{3}$ & 557.7 \\
\hline $7 \mathrm{H}_{2} \mathrm{O} . \mathrm{MgSO}_{4}$ & 27.5 \\
\hline $7 \mathrm{H}_{2} \mathrm{O} . \mathrm{FeSO}$ & \\
\hline $\mathrm{KCl}$ & 2.5 \\
\hline
\end{tabular}


Table 2: Characteristics of the Membrane Used in the Experimental Set-up

\begin{tabular}{|c|c|}
\hline Parameters & Membrane Module \\
\hline \hline Membrane module & Flat sheet \\
\hline Membrane material & Chlorinated polyethylene (PE) \\
\hline Nominal pore size & $0.45 \mu \mathrm{m}$ \\
\hline Effective area & $0.11 \mathrm{~m}^{2}$ \\
\hline Chemical formulate & {$\left[-\mathrm{CH}_{2}-\mathrm{CH}_{2}-\right] \mathrm{n}$} \\
\hline Thickness & $127 \mu \mathrm{m}$ \\
\hline Clean water flow & $120>\mathrm{ml} / \mathrm{min}$ \\
\hline
\end{tabular}

The membrane-filtered effluent was collected by a suction pump. The transmembrane pressure (TMP) was measured by a pressure gauge and a vacuum pump supplied a constant TMP of 0.1 bar for the membrane. The AMBR was operated at ambient temperature (approximately $20-25^{\circ} \mathrm{C}$ ). Since the tests were carried out at a constant TMP, the hydrodynamic retention time (HRT) of the system varied due to the flux change. However, the average value of the HRT was about $29 \pm 2 \mathrm{~h}$ when the system reached the pseudo-steady flux. Except for samplings, the solid retention time (SRT) was almost infinite since there was no wasted sludge.

In addition, the activated sludge mixed culture in this research was taken from a petrochemical wastewater plant. Hence, the sludge microorganisms were already adapted to the oily hydrocarbons pollutants of the wastewater.

\subsection{Analysis of Parameters}

Standard methods were adopted for analysis and measuring of different parameters such as chemical oxygen demand (COD), the mixed liquid suspended solids (MLSS) concentration, the mixed liquid volatile suspended solids (MLVSS) concentration and the sludge volume index (SVI) [19]. The EPS can be divided into soluble and non-soluble portions. The soluble portion is considered as loosely bound EPS (LB-EPS) [20]. Several methods have been used to extract extracellular polymers from bacterial cultures. In the present study, formaldehyde and sodium hydroxide were used for EPS extraction. A sludge suspension was first agitated via vortex at room temperature for 5 min and then dewatered by centrifuging in a $10 \mathrm{~mL}$ test tube at $3500 \mathrm{rpm}$ for $10 \mathrm{~min}$ (Hettich, Universal 320, Germany). The supernatant contained LB-EPS, which were collected for analyses including determination of the protein extracellular polymeric substance $\left(E P S_{P}\right)$ and of the polysaccharidebased extracellular polymeric substance $\left(E P S_{C}\right)$ (Solution No.1). After the extraction of LB-EPS, the sludge was pelleted and resuspended in $5 \mathrm{~mL}$ of $8.5 \% \mathrm{NaCl}$ and $0.22 \%$ formaldehyde and was shaken for $1 \mathrm{~min}$. Next, $5 \mathrm{~mL}$ of $0.5 \% \mathrm{NaOH}$ was added to the solution and it was shaken for another minute (solution No.2). Both solutions No.1 and No.2 were then centrifuged at $10000 \mathrm{rpm}$ for $15 \mathrm{~min}$ to separate the remaining suspended materials. The solutions were then filtered through filter paper $(0.45$ $\mu \mathrm{m})$ and the amount of tight bound EPS (TB-EPS) and the LB-EPS in the filtrate was determined. Both the LBEPS and TB-EPS extractions were analyzed for protein and polysaccharide contents. The EPS were analyzed by a UV/VIS spectrophotometer (WTW, Spectro Flex 6600 , Germany). According to the modified Lowry method [21], bovine serum albumin (Sigma) is used as the standard solution. The EPS $C$ content was determined by the anthrone-sulphuric acid method taking glucose as the standard $[22,18]$.

\subsubsection{Measurement of Filtration Resistance}

The resistance-in-series model was applied to calculate the total membrane resistance $\left(R_{t}\right)$ as a summation of clean membrane resistance $\left(R_{m}\right)$, pore blocking fouling $\left(R_{p}\right)$, and cake layer fouling $\left(R_{c}\right)$ presented by equation (1):

$\mathrm{R}_{\mathrm{t}}=\left(\mathrm{R}_{\mathrm{m}}+\mathrm{R}_{\mathrm{p}}+\mathrm{R}_{\mathrm{c}}\right)=\frac{\mathrm{TMP}}{\mu \mathrm{J}}$

where $J$ is the permeate flux $\left(\mathrm{Lm}^{-2} \cdot \mathrm{h}^{-1}\right)$ and $\mu$ is the permeate viscosity (mPa.s). The procedure used to obtain each resistance value conforms to the work by Meng [20].

\subsubsection{Oxygen Transfer Coefficient Measurement}

The dynamic biological method was used for measurement of oxygen transfer rate and $\mathrm{k}_{\mathrm{L}} a$ was determined according to the oxygen mass balance as following:

$\frac{\mathrm{dC}_{\mathrm{L}}}{\mathrm{dt}}=\mathrm{k}_{\mathrm{L}} \mathrm{a}\left(\mathrm{C}_{\mathrm{S}}-\mathrm{C}_{\mathrm{L}}\right)-$ OUR

where $\mathrm{dC}_{\mathrm{L}} / \mathrm{dt}$ is the variation of dissolved oxygen concentration with time (mg/L.s), $\mathrm{k}_{\mathrm{L}} a$ is the volumetric overall mass transfer coefficient for the liquid phase at $20^{\circ} \mathrm{C}\left(\mathrm{S}^{-1}\right), \mathrm{C}_{\mathrm{s}}$ denotes the saturation concentration of $\mathrm{DO}$ at $20^{\circ} \mathrm{C}(\mathrm{mg} / \mathrm{L}), \mathrm{C}_{\mathrm{L}}$ stands for the concentration of DO at $20^{\circ} \mathrm{C}(\mathrm{mg} / \mathrm{L})$ and OUR is oxygen uptake rate (mg/L.s) [12]. In microbial presence, the dissolved 
oxygen concentration is decreased by the respiration of microorganisms then aeration was restarted in the same manner as for the case with the clean water $[24,25,26]$. Dissolved oxygen concentration was measured by a DO meter (Electrode Oxymeter WTWoxi 340i).

\subsubsection{Oxygen Uptake Rate Measurement}

The oxygen uptake rate and the specific oxygen uptake rate were measured as parameters for evaluation of biological activity. The OUR was determined by measurement of the dissolved oxygen concentration in the air-tight vessel with $400 \mathrm{~mL}$ volume. Bacterial medium was mixed in the vessel with a magnet stirrer and the respiration of microorganism decreased the dissolved oxygen content in the vessel. A drop in the dissolved oxygen content from 5 to 2 $\mathrm{mg} / \mathrm{L}$ was measured after switching off the aeration. The DO concentration changes were recorded in the course of time. The slope of DO variation versus time gives OUR values and by dividing the OUR to the MLSS concentrations, the sOUR value was obtained [15].

\section{RESULTS AND DISCUSSION}

\subsection{The Effect of Aeration on Mass Transfer Coefficient}

By increasing the aeration rate, more intense turbulence takes place inside the airlift membrane bioreactor and hence mass transfer in the liquid phase will be improved. This is in harmony with the results presented in Figure 2. As shown also in this figure, by increasing the MLSS from 3.2 to $5.5 \mathrm{~g} / \mathrm{L}$ in the AMBR, the mass transfer coefficient decreases. A rise in the MLSS concentration leads to a higher viscosity of

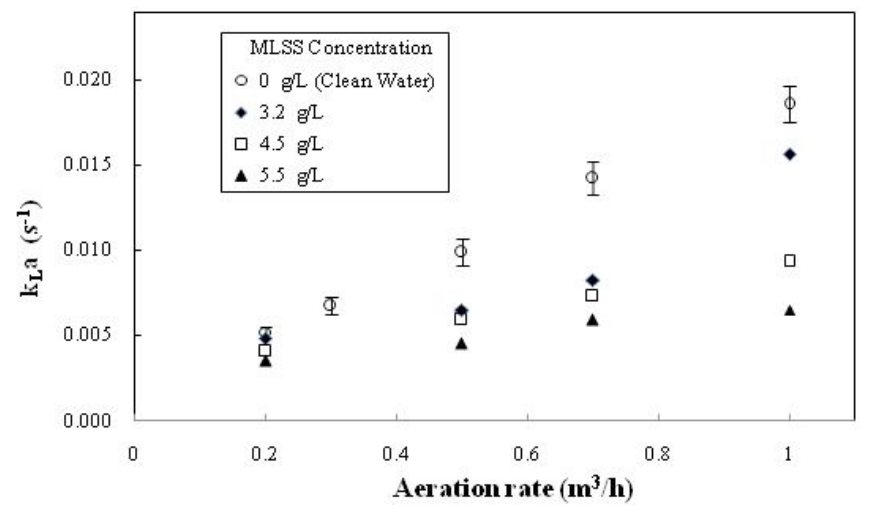

Figure 2: Profiles of volumetric oxygen mass transfer coefficient $(k\llcorner a)$ versus aeration rate in airlift membrane bioreactor at $298 \mathrm{k}$. the bioreactor retentate $[26,27]$. An increase in viscosity has been shown to have a negative influence on the oxygen transfer coefficient $[28,29]$. On the other hand, in high MLSS concentration, oxygen solubility was lowered therefore in high cell density cultures, resistance to oxygen transfer from the gaseous to the liquid phase was increased and oxygen transfer to liquid phase become more difficult [30].

From Figure 2 it could also be concluded that the effect of aeration rate on the $\mathrm{k}_{\mathrm{L}} a$ at low cell concentration is more significant.

The effects of aeration rate on $\mathrm{k}_{\mathrm{L}} a$ for different carbon sources were also studied. In the first experiments, glucose was employed as the carbon source and in the second set of experiments, n-hexadecane was chosen as the carbon source to compare their effects. In both series of the experiments, the MLSS and the operating conditions were similar and an equal COD loading rate for each carbon source was applied. As shown in Figure 3, an increase in aeration rate led to an enhancement of $k_{L} a$. In both cases, however, the amount of $\mathrm{k}_{\mathrm{L}} a$ in glucose fed mixture is about twice that of the $n$-hexadecane mixture. The same results were observed in MLSS of $4 \mathrm{~g} / \mathrm{L}$.

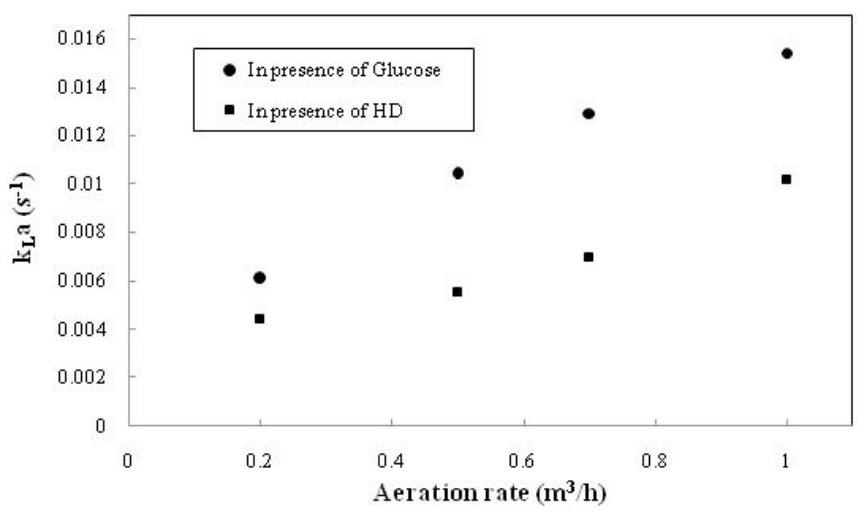

Figure 3: Mass transfer coefficient in constant MLSS $=5(\mathrm{~g} / \mathrm{L})$ in different aeration rate, with injection Glucose and with injection $\mathrm{n}$-hexadecane as a feed.

In biological wastewater treatment, oily compounds could be transformed to some bioproducts that act as surfactant agents. These compounds in the wastewater liquid phase affect the oxygen transfer, hydraulic properties and even biological activity [31]. According to Painmanakul et al., the presence of surfactants at the liquid-bubble interface affect mass transfer by changing the composition and thickness of liquid film around the air bubble [32]. The results showed that $\mathrm{n}$-hexadecane as an oily pollutant has the same effects 
and causes a meaningful decrease in the mass transfer coefficient.

The $\alpha$-factor values were compared at various aeration rates, the MLSS concentrations and carbon sources (Figure 4). The results showed that variation of the aeration rate for each MLSS concentration has no significant effect on the $\alpha$-factor. A considerable variation in the $\alpha$-factor related to presence of $n$ hexadecane was observed in comparison with the slight effect of glucose at different concentrations of MLSS (Table 3).

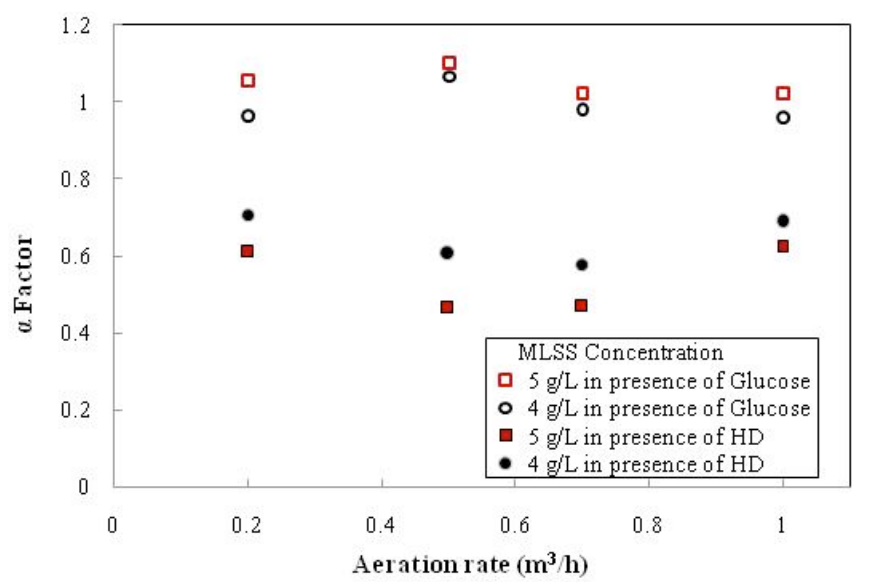

Figure 4: $\alpha$-factor values in different aeration rates, MLSS concentration and carbon source in AMBR.
Table 3: $\alpha$-factor Values Obtained at Two Different MLSS and Two Feed

\begin{tabular}{|c|c|c|}
\hline \multirow{2}{*}{$\begin{array}{c}\text { MLSS } \\
\text { Concentration (a/L) }\end{array}$} & \multicolumn{2}{|c|}{$\alpha$-factor based on carbon source } \\
\cline { 2 - 3 } & Hexadecane & Glucose \\
\hline \hline 4 & $0.56_{ \pm} 0.0087$ & $1.04_{ \pm} 0.0019$ \\
\hline 5 & $0.64_{ \pm} 0.0055$ & $1.00 \pm 0.0057$ \\
\hline
\end{tabular}

\subsection{The Effect of Aeration on Oxygen Uptake Rate}

Figure 5 shows the MLSS, MLVSS and oxygen uptake rate variations at different aeration rates. In the four rising aeration rates, the amount of MLSS and MLVSS concentration was increased slowly. In the first interval, despite high MLSS concentration, the lowest OUR has been observed. The OUR is a suitable parameter for representation of microorganisms' activity. Accordingly, a low OUR is indicative of presence of a high percentage of dead or inactive cells in the sludge. Generally, in constant MLVSS, increase of OUR could be interpreted as a higher respiratory activity of bacteria. In Figure 5, higher OUR also could be seen at higher aeration rate. Thus, the activity of microorganisms significantly increased with the aeration rate.

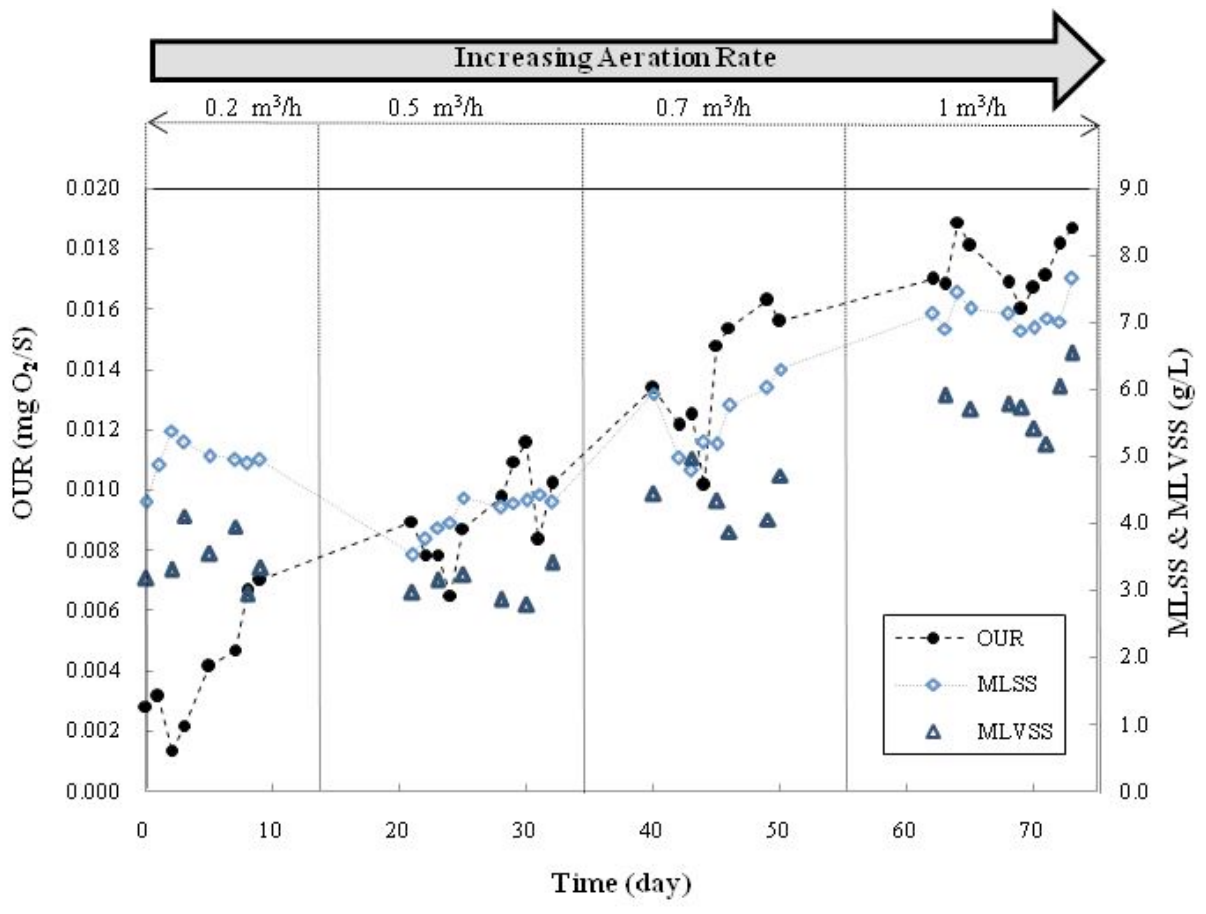

Figure 5: Variation of OUR, MLSS and MLVSS vs. Time in AMBR. 


\subsection{The Effect of Aeration on Treatment Efficiency}

The results of COD removal in AMBR at the four aeration intensities have been shown in Figure 6 . The removal efficiency of $n$-hexadecane was attained over $93 \%$ for all aeration rates. The efficiency of COD removal in the bioreactor due to biological activity alone varies from 60 to $86 \%$ in respect to 0.2 to $1 \mathrm{~m}^{3} / \mathrm{h}$ aeration rates. As the aeration rate increased, the OTR and DO concentration and hence microbial activities increased so that the COD removal efficiency in the bioreactor rose. While aeration rate increased, more shear stress imposed on membrane surface and it hindered biofilm formation on membrane surface. The biofilm has a positive effect on the COD removal in MBRs [33]. In fact, the membrane contribution to COD removal depends on the biofilm layer thickness formed on the membrane surface [7] so that higher aeration intensity has resulted in the lower removal efficiency by membrane and deposited biofilm on the membrane surface. On the other hand, there are two simultaneous processes taking place during an AMBR operation counteracting each other. By increasing the aeration rate, the portion of biological process in the COD removal increases while the portion of physical removal (membrane) is reduced.

\subsection{The Effect of Aeration on Fouling}

The membrane permeate flux was measured to study the membrane fouling behavior at four mentioned aeration intensities. The membrane flux declined during all experiments due to the membrane fouling. The evolution of permeate flux during the first hour of the membrane filtration in AMBR is presented in Figure 7. Previous studies indicated that the cake layer resistance has the main portion of total hydraulic resistance of the fouled membrane in membrane bioreactors [34,21]. The higher aeration intensity induced shear stress and turbulence on the membrane surface, and led to removal of the cake layer from the membrane surface [35]. Also higher shear stress led to severe breakage of flocs. Smaller flocs and colloids deposit on membrane pores easily and increase the contribution of irreversible membrane fouling in total hydraulic resistance. It can be seen that the permeate flux in all aeration rate drastically declined after $60 \mathrm{~min}$ filtration. The fouling rate decreased with enhancement of aeration intensities in the initial filtration time.

The dynamics of the permeate flux during experiments, presented in Figure 8, shows that the decline in permeate flux at aeration rate of 0.2 and 0.5 $\mathrm{m}^{3} / \mathrm{h}$ was more severe than 0.7 and $1 \mathrm{~m}^{3} / \mathrm{h}$. It seems that low shear stress at low aeration could not remove

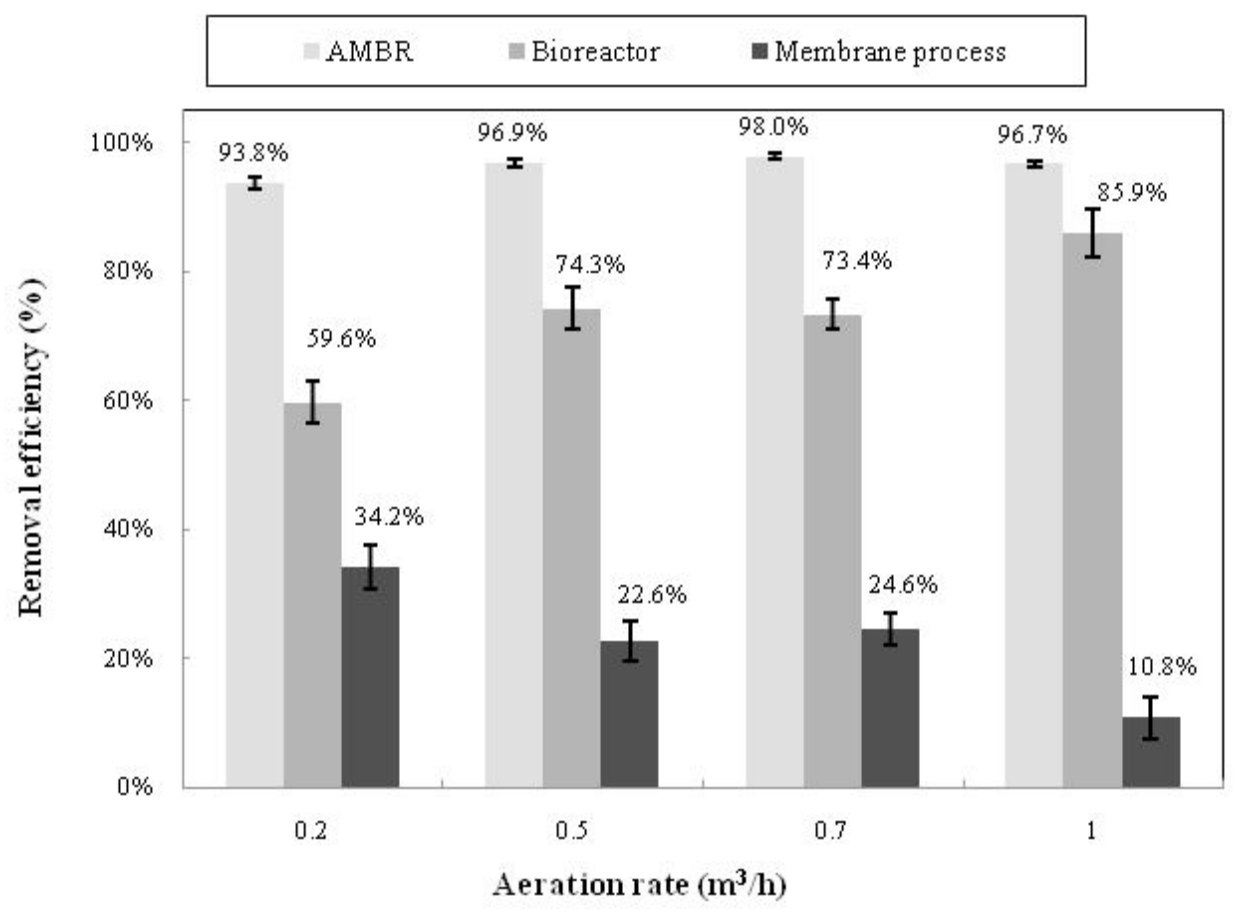

Figure 6: Comparison of removal efficiency at various aeration rates in separated portion of biological and physical processes (AMBR, bioreactor and membrane). 
deposited cake layer on membrane surface. But in higher aeration, higher turbulence on membrane surface prevents the deposition of suspended materials on membrane surface and hence reduced the membrane fouling.

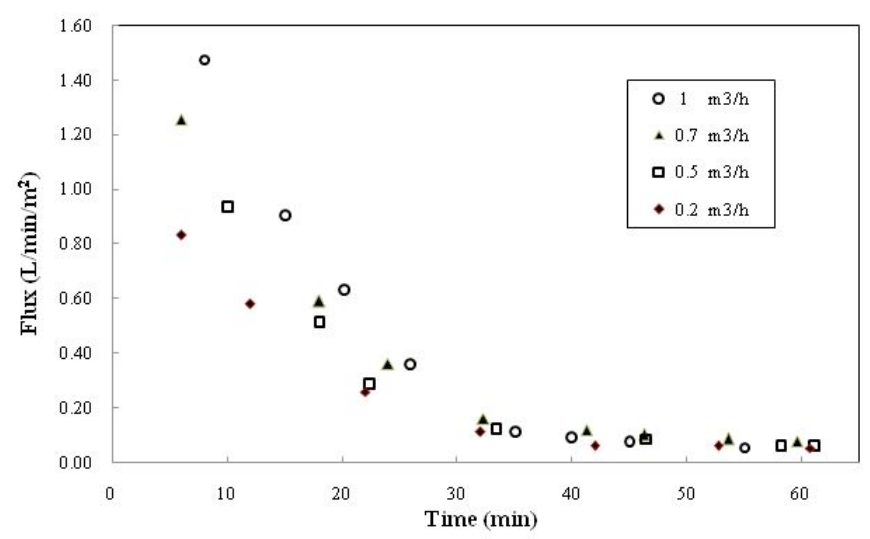

Figure 7: Permeate flux during first hour of the membrane filtration in four aeration rates.

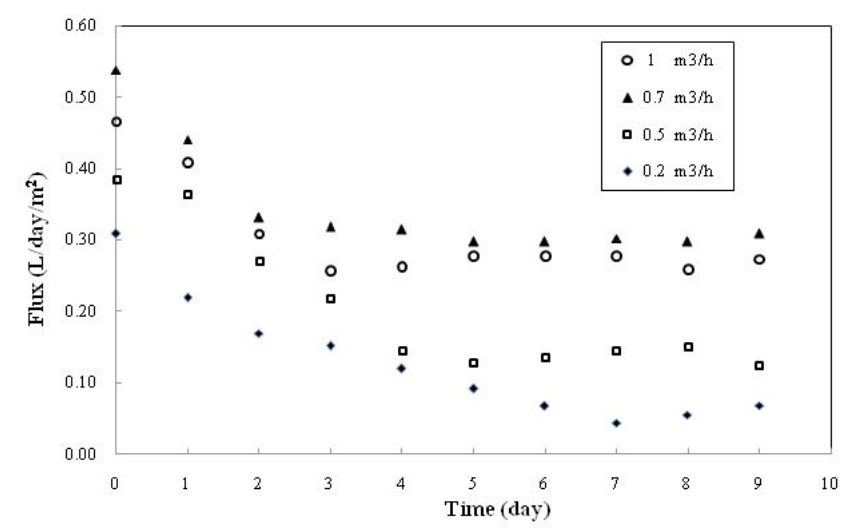

Figure 8: Permeate flux of the membrane filtration during experiments in four aeration rates.

In the initial 60 min period, the membrane permeate flux was influenced by the shear stress. On the other hand, comparing the changes of biomass characteristics and shear stress effects, one concludes that shear stress is the dominant phenomenon. The shear stress generated by the air bubbles can remove the foulants deposited on the membrane surface. But through the time, the aeration intensity affects biomass characteristics that have significant impacts on the membrane fouling. In $0.7 \mathrm{~m}^{3} / \mathrm{h}$ aeration rate, the permeate flux is more than $1 \mathrm{~m}^{3} / \mathrm{h}$ because higher aeration intensity and high turbulence can result in flocs breakage and the rising of EPS concentration which deteriorate of sludge filterability [36]. It seems that there is an optimum aeration rate that removes cake layer but does not break flocs structures.

The SVI and EPS as two biomass related characteristics were measured to study their effects on membrane fouling. At the high aeration intensity, the breakage of sludge flocs and release of EPS were observed. The sludge settling properties according to SVI measurement were significantly deteriorated at aeration rate of $1 \mathrm{~m}^{3} / \mathrm{h}$.

In Figure 9, the average values of EPS in different aeration rates have been shown. The results showed that the EPS concentration and portion of loosely bound EPS (LB-EPS) increase with aeration rate. As mentioned above, with increasing of aeration intensities, shear stress on sludge flocs increases; leading to the flocs breakage, decrease in flocs size and release of tightly bound EPS (TB-EPS) into the supernatant which is in agreement with the results obtained by Azami et al. [18]. Increase in aeration rate brings about higher oxygen uptake rate and activity of microorganisms resulting in increment of soluble EPSs concentration. As a result, at a higher aeration rate of 1 $\mathrm{m}^{3} / \mathrm{h}$, the concentration of both the protein and the polysaccharide LB-EPS increases due to the increment of the activated sludge viability and flocs breakage. The LB-EPS is one of the main parameters triggering the membrane fouling in membrane bioreactors [37]. As a result, although the higher aeration intensity mitigates membrane fouling, the fouling in aeration rate of $1 \mathrm{~m}^{3} / \mathrm{h}$ is more than aeration rate $0.7 \mathrm{~m}^{3} / \mathrm{h}$.

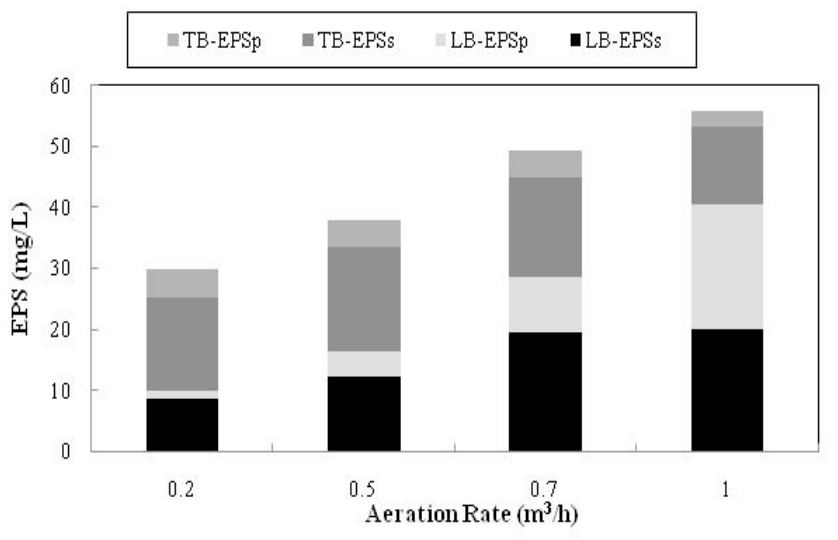

Figure 9: Average values of EPS in different aeration intensities in AMBR. (Loosely Bound EPS, Tight Bound EPS; protein and polysaccharide).

To better study the membrane fouling, pore blocking and cake resistance were analyzed. As shown in Figure 10, the contribution of cake resistance in total 


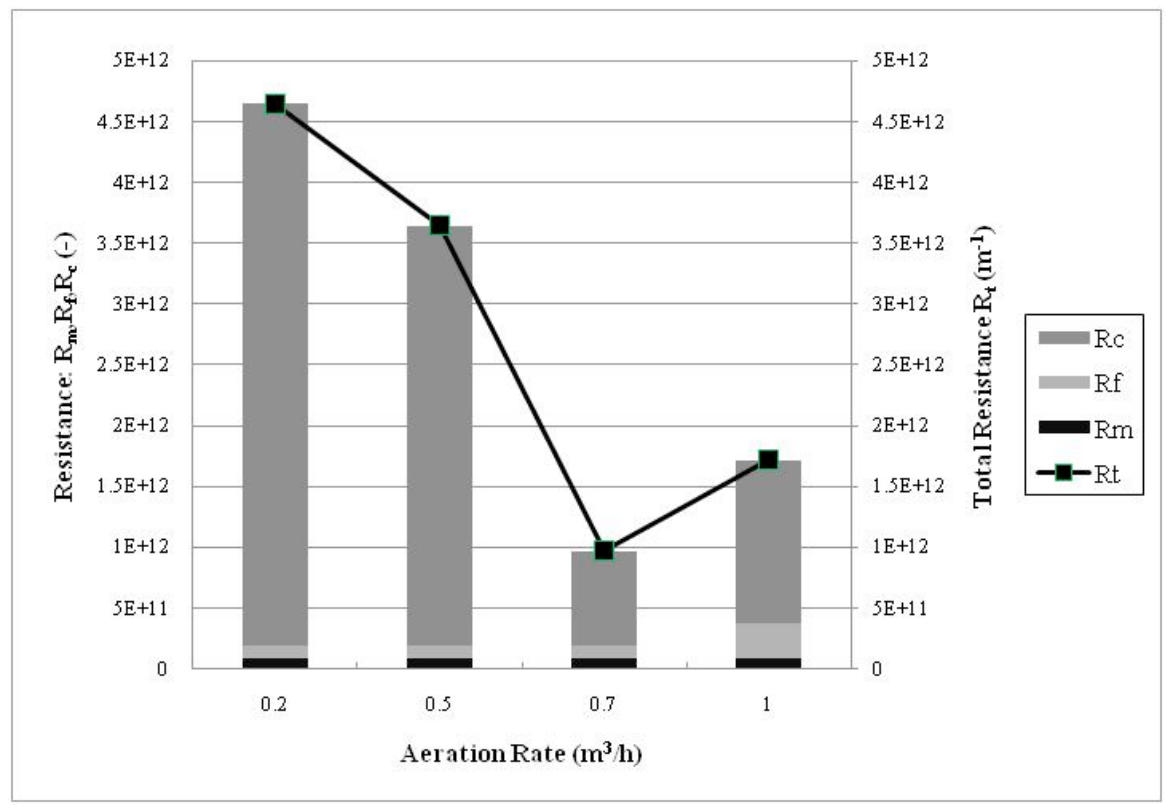

Figure 10: Membrane, pore blocking and cake resistance in four aeration rates after each run, the absolute value of total resistance has presented in each column.

resistance is in the range of $78 \%$ to $96 \%$. The results had shown that the cake resistance in aeration rate $0.2 \mathrm{~m}^{3} / \mathrm{h}$ was more than other intensities, indicating that aeration had great impacts on the removal of cake layer. Furthermore, the pore blocking resistance increased with the aeration intensity, especially for aeration rate $1 \mathrm{~m}^{3} / \mathrm{h}$. These results show that a severe irreversible fouling occurred in high aeration rate.

According to other research works, at high aeration intensities, the deposition of particles into the membrane pores would result in severe irreversible fouling [23]. Among the four applied aeration rates, the total resistance in aeration rate of $0.7 \mathrm{~m}^{3} / \mathrm{h}$ was the lowest.

\section{CONCLUSIONS}

Experiments were conducted in an airlift membrane bioreactor with different aeration rates. Our results showed that:

- In the AMBR with increasing MLSS concentrations, the oxygen transfer rates decreases and it could be concluded that the effect of aeration rate on the $\mathrm{k}_{\mathrm{L}} \mathrm{a}$ at low cell concentration is more significant. In addition, an increase in the aeration rate led to an enhancement of $\mathrm{k}_{\mathrm{L}} \mathrm{a}$. In investigation of feed effect on $k_{\llcorner} a$, for the glucose fed mixture, $k_{\llcorner} a$ is about twice that of the $n$-hexadecane mixture.
Thus, $\mathrm{n}$-hexadecane as an oily pollutant can decrease the $k_{L}$ a parameter significantly.

- Measurement of the oxygen uptake rate showed that increasing aeration rates is in favor of increasing the biological activity. As a corollary, an increase in the COD removal efficiency (from 60 to $86 \%$.) in the bioreactor can be attributed to the biological activities alone.

- The removal efficiency of $n$-hexadecane in AMBR at the four aeration intensities was achieved over $93 \%$. On the other hand, the membrane contribution to the COD removal which depends on the biofilm layer thickness decreases with the aeration rate.

- The dynamics of the permeate flux during the experiments showed that, in a long term, the permeate flux for $0.7 \mathrm{~m}^{3} / \mathrm{h}$ aeration rate is more than $1 \mathrm{~m}^{3} / \mathrm{h}$ because higher turbulence can result in flocs breakage and rising of EPS concentration which deteriorates the sludge filterability.

- As discussed, by increasing the aeration intensities, the shear stress on sludge flocs increases leading to the flocs breakage, decrease in flocs size and release of tightly bound EPS. On the other hand, at high 
aeration intensity the deposition of particles into the membrane pores would cause severe irreversible fouling. Among the four applied aeration rates, the total resistance in aeration rate of $0.7 \mathrm{~m}^{3} / \mathrm{h}$ was the lowest.

The results showed that air flow rates appeared as a determining criterion to optimize the operation efficiency. Aeration rate of $0.7 \mathrm{~m}^{3} / \mathrm{h}$ was the evaluated as the optimum value for the studied system. These observations should be completed by further experiments to be carried out on other biomass characteristics and its effects on aeration efficiency of an AMBR.

\section{ACKNOWLEDGEMENT}

Authors would like to thank $\mathrm{H}$. Azami for his technical assistance. Authors would also like to acknowledge the financial support of University of Tehran for this research under grant number 8104956/1/02.

\section{APPENDIX}

\section{Nomenclature}

$$
\begin{aligned}
& \text { AMBR = Airlift membrane bioreactor } \\
& \mathrm{C}_{\mathrm{L}}=\text { Dissolved oxygen concentration }(\mathrm{mg} / \mathrm{L}) \\
& \mathrm{COD}=\text { Chemical oxygen demand }(\mathrm{mg} / \mathrm{L}) \\
& \text { Cs = Saturation concentration of dissolved } \\
& \text { oxygen (mg/L) } \\
& \text { DO = Dissolved oxygen concentration }(\mathrm{mg} / \mathrm{L}) \\
& \text { EPS }=\text { Extracellular polymeric substances } \\
& \mathrm{HD}=\mathrm{n} \text {-Hexadecane } \\
& \text { HRT = Hydrodynamic retention time } \\
& \mathrm{J} \quad=\quad \text { Permeate flux }\left(\mathrm{Lm}^{-2} \cdot \mathrm{h}^{-1}\right) \\
& \mathrm{k}_{\mathrm{L}}=\text { Mass transfer coefficient in liquid phase } \\
& \left(\mathrm{m} \cdot \mathrm{s}^{-1}\right) \\
& \mathrm{k}_{\mathrm{L}} \mathrm{a}=\text { Volumetric mass transfer coefficient } \\
& \left(\mathrm{S}^{-1}\right) \text {, } \\
& \text { LB-EPS = Loosely bound EPS } \\
& \text { MBR = Membrane bioreactor }
\end{aligned}
$$

$$
\begin{aligned}
& \text { MLSS = Mixed liquor suspended solids(g/L) } \\
& \text { MLVSS }=\text { Mixed liquor volatile suspended solids } \\
& (g / L) \\
& \text { OTR = Oxygen transfer rate } \\
& \mathrm{R}_{\mathrm{c}} \quad=\quad \text { Cake layer fouling }\left(\mathrm{m}^{-1}\right) \\
& \mathrm{R}_{\mathrm{m}} \quad=\quad \text { Clean membrane resistance }\left(\mathrm{m}^{-1}\right) \\
& \mathrm{R}_{\mathrm{p}} \quad=\text { Pore blocking fouling }\left(\mathrm{m}^{-1}\right) \\
& \mathrm{R}_{\mathrm{t}}=\text { Total hydraulic resistance }\left(\mathrm{m}^{-1}\right) \\
& \text { sMBR = Submerged membrane bioreactor } \\
& \mathrm{SMP}_{\mathrm{COD}}=\text { Soluble microbial product of COD } \\
& \text { concentration } \\
& \text { SOUR }=\text { Oxygen uptake rate }\left(\mathrm{mg} \mathrm{O}_{2} / \mathrm{g}-\mathrm{MLVSS}-\mathrm{h}\right) \\
& \text { SRT }=\text { Solid retention time } \\
& \text { SVI }=\text { Sludge volume index }(\mathrm{mL} / \mathrm{g}) \\
& \mathrm{T}=\text { Time }(\mathrm{s}) \\
& \text { TB-EPS }=\text { Tight bound EPS } \\
& \mu \quad=\text { Viscosity (mPa.s) }
\end{aligned}
$$

\section{REFERENCES}

[1] Stephenson T, Brindle K, Judd S, Jefferson B. Membrane bioreactors for wastewater treatment. London: IWA Publishing; 2000.

[2] Germain E, Stephenson T. Biomass characteristics, aeration and oxygen transfer in membrane bioreactors: Their interrelations explained by a review of aerobic biological processes. Envir Sci and Bio/Tech 2005; 4: 223-33.

[3] Judd S. The MBR Book: Principles and applications of membrane bioreactors in water and wastewater treatment. Oxford: Elsevier; 2006.

[4] Nywening J, Zhoub $\mathrm{H}$. Influence of filtration conditions on membrane fouling and scouring aeration effectiveness in submerged membrane bioreactors to treat municipal wastewater. Water Res 2009; 43: 3548-3558. http://dx.doi.org/10.1016/j.watres.2009.04.050

[5] Sofia A, Ng WJ, Ong SL. Engineering design approaches for minimum fouling in submerged MBR. Desalination 2004; 160: $67-74$ http://dx.doi.org/10.1016/S0011-9164(04)90018-5

[6] Khalili-Garakani A, Mehrnia MR, Mostoufi N, Sarrafzadeh $\mathrm{MH}$. Analyze and control fouling in an airlift membrane bioreactor: CFD simulation and experimental studies. Process Biochem 2011; 46: 1138-45. http://dx.doi.org/10.1016/j.procbio.2011.01.036

[7] Mafirad S, Mehrnia MR, Azami H, Sarrafzadeh MH. Effects of biofilm formation on membrane performance in submerged membrane bioreactors. Biofouling 2011; 27: 477-85. http://dx.doi.org/10.1080/08927014.2011.584619 
[8] Krause S, Cornel P, Wagner M. Comparison of different oxygen transfer testing procedures in full-scale membrane bioreactors. Water Sci Technol 2003; 47: 169-76.

[9] Churchouse S. Membrane Bioreactors: Going from Laboratory to Large Scale -Problems to Clear Solutions, In: Presented at membranes and the environment. University of Oxford, 2002; 14-17 July.

[10] Fletcher H, Mackley T, Judd S. The cost of a package plant membrane bioreactor. Water Res 2007; 41: 2627-35. http://dx.doi.org/10.1016/j.watres.2007.02.038

[11] Mueller JA, Boyle WC, Popel HJ. Aeration: principles and practice. Boca Raton: CRC Press; 2002.

[12] Garcia-Ochoa F, Gomez E. Bioreactor scale-up and oxygen transfer rate in microbial processes: An overview. Biotechnol Adv 2009; 27:153-76.

http://dx.doi.org/10.1016/j.biotechadv.2008.10.006

[13] Ozbek B, Gayik S. The studies on the oxygen mass transfer coefficient in a bioreactor. Process Biochem 2001; 36: 72941. http://dx.doi.org/10.1016/S0032-9592(00)00272-7

[14] Germain E, Nellesb F, Drews A, Pearcec P, Kraumeb M, Reida $\mathrm{E}$, et al. Biomass effects on oxygen transfer in membrane bioreactors. Water Res. 2007; 41:1038-1044. http://dx.doi.org/10.1016/j.watres.2006.10.020

[15] Hasar H, Kinaci C. Empirical model representing microbial activity in a submerged MBR treating strength wastewater. Desalination 2004; 170: 161-67. http://dx.doi.org/10.1016/j.desal.2004.02.097

[16] Drews A, Vocks M, Iversen I, Lesjean B, Kraume M. Influence of unsteady membrane bioreactor operation on EPS formation and filtration resistance. Desalination 2006; 192: 19.

http://dx.doi.org/10.1016/i.desal.2005.04.130

[17] Yun MA, Yeon KM, Park JS, Lee CH, Chun JS, Lim DJ. Characterization of biofilm structure and its effect on membrane permeability in MBR for dye wastewater treatment. Water Res 2006; 40: 45-52.

http://dx.doi.org/10.1016/j.watres.2005.10.035

[18] Azami H, Sarrafzadeh MH, Mehrnia MR. Fouling in membrane bioreactors with various concentrations of dead cells. Desalination 2011; 278: 373-80. http://dx.doi.org/10.1016/j.desal.2011.05.052

[19] APHA. Standard methods for the examination of water and wastewater. 19th ed. Baltimore: American Public Health Association; 1995.

[20] Le-Clech $P$, Chen V, Fane T. Fouling in membrane bioreactors used in wastewater treatment. J Membr Sci 2006; 284:17-53. http://dx.doi.org/10.1016/j.memsci.2006.08.019

[21] Drews A. Membrane fouling in membrane bioreactors characterization, contradictions, cause and cures. J Membr Sci 2010; 363: 1-28.

http://dx.doi.org/10.1016/j.memsci.2010.06.046

[22] Lesjean B, Rosenberger S, Laabs C, Jekel M, Gnirss R, Amy G. Correlation between membrane fouling and soluble/colloidal organic substances in membrane bioreactors for municipal wastewater treatment, WEMT, Seoul, 2004.

[23] Meng F, Yang F, Shi B, Zhang H. A comprehensive study on membrane fouling in submerged membrane bioreactors operated under different aeration intensities. Sep Purif Technol 2008; 59: 91-100.

http://dx.doi.org/10.1016/j.seppur.2007.05.040

[24] Chisti Y, Moo-Young M. Airlift reactors: Characteristics, applications and design considerations. Chem Eng Commun 1987; 60: 195-242.

http://dx.doi.org/10.1080/00986448708912017

[25] Korpijarvi J, Oinas $P$, Reunanen J. Hydrodynamics and mass transfer in an airlift reactor. Chem Eng Sci 1999; 54: 2255-62. http://dx.doi.org/10.1016/S0009-2509(98)00439-4

[26] Bandaiphet C, Prasertsan P. Effect of aeration and agitation rates and scale-up on oxygen transfer coefficient, $\mathrm{kLa}$ in exopolysaccharide production from Enterobacter cloacae WD7. Carbohyd Polym 2006; 66: 216-28. http://dx.doi.org/10.1016/j.carbpol.2006.03.004

[27] Cornel $\mathrm{P}$, Wagner $\mathrm{M}$, Krause $\mathrm{S}$. Investigation of oxygen transfer rates in full scale membrane bioreactors. Water Sci Technol 2003; 47: 313-19.

[28] Kilonzo PM and Margaritis A. The effects of non-Newtonian fermentation broth viscosity and small bubble segregation on oxygen mass transfer in gas-lift bioreactors: a critical review. Biochem Eng J 2004; 17: 27-40.

http://dx.doi.org/10.1016/S1369-703X(03)00121-9

[29] Sato T, Ishii Y. Effects of activated-sludge properties on water flux of ultrafiltration membrane used for human excrement treatment. Water Sci Technol 1991; 23: 1601-8.

[30] Badino JAC, Facciotti MCR, Schmidell W. Volumetric oxygen transfer coefficients $\left(k_{\llcorner} a\right)$ in batch cultivations involving nonNewtonian broths. Biochemical Engineering 2001; 8: 111-9. http://dx.doi.org/10.1016/S1369-703X(01)00092-4

[31] Garcia-Ochoa F, Gomez E. Prediction of gas-liquid mass transfer in sparged stirred tank bioreactors. Biotechnol Bioeng 2005; 92: 761-72. http://dx.doi.org/10.1002/bit.20638

[32] Painmanakul $P$, Loubière $K$, Hébrard G, Mietton-Peuchot $M$, Roustan M. Effect of surfactants on liquid-side mass transfer coefficients. Chem Eng Sci 2005; 60: 6480-91.

http://dx.doi.org/10.1016/j.ces.2005.04.053

[33] Hamoda M, Al-Sharekh H. Sugar wastewater treatment with aerated fixed-film biological systems. Water Sci Technol 1999; 40: 313-21. http://dx.doi.org/10.1016/S0273-1223(99)00400-X

[34] Azami H, Mehrnia MR, Sarrafzadeh MH, Mafirad S, Kazemzadeh M, Madaeni SS. Effect of cations on activated sludge characterization and membrane fouling in membrane bioreactor for waste water treatment. Journal of Chemical and Petroleum Engineering 2010; 44: 1-8.

[35] Le-Clech P, Jefferson B, Judd S. Impact of aeration, solids concentration and membrane characteristics on the hydraulic performance of a membrane bioreactor. J Membr Sci 2003; 218: 117-29.

http://dx.doi.org/10.1016/S0376-7388(03)00164-9

[36] Zhang J, Chua HC, Zhou J, Fane AG. Factors affecting the membrane performance in submerged membrane bioreactors. J Membr Sci 2006; 284: 54-66. http://dx.doi.org/10.1016/j.memsci.2006.06.022

[37] Wang F, Shan L, Ji M. Components of released liquid from ultrasonic waste activated sludge disintegration. Ultrason Sonochem 2006; 13: 334-338. http://dx.doi.org/10.1016/i.ultsonch.2005.04.008 